\title{
Pengelolaan APBDES di Desa Tambala Kecamatan Tombariri Kabupaten Minahasa
}

\author{
Marthinus M. Mandagi ${ }^{\text {a }}{ }^{*}$, Sisca B. Kairupan ${ }^{\mathrm{b}, 2}$, Mariam Wullur ${ }^{\mathrm{c}, 3}$ \\ ${ }^{a}$ Universitas Negeri Manado, Ilmu Administrasi Negara, Tondano Indonesia \\ 1 marthinusmandagi@yahoo.com* siscakairupan@unima.ac.id; mariamwullur@unima.ac.id
}

\section{INFO A RTIKEL}

Diterima 00 April 00

Disetujui 00 Oktober 00

\section{Key word:}

APBDes,

Management,

Tombariri District

\section{A B S T R A C T}

In general, the stages of the implementation of the APBDes

Management Program in the VillageTambala, Tombariri Subdistrict, Minahasa Regency, in the management of the APBDes, it is not yet fully running properly where the management of the APBDes / village finances is still not in accordance with the existing budget. This type of research uses descriptive qualitative research. The focus in this research can be formulated as follows: How is the APBDes management process, Implementation of Village Fund Allocation (ADD) in Tambala Village, Tombariri District, Minahasa Regency. The location taken in the study is in Tambala Village, Tombariri District, Minahasa Regency. Sampling for qualitative research data was carried out purposively and for further information it was determined by snow ball sampling technique. To obtain data related to the problems to be studied, it is done by: Interviews, Documentation / literature studies. The data obtained were analyzed using descriptive techniques with a qualitative approach. In the data analysis model consists of three components, namely data reduction, data presentation, and drawing conclusions.

\section{INTISARI}

\section{Kata kunci: \\ APBDes,}

Pengelolaan,

Kecamatan Tombariri
Secara umum tahapan pelaksanaan Program Pengelolahan APBDes di Desa Tambala Kecamatan Tombariri Kabupaten Minahasa dalam pengeloaan APBDes belum sepenuhnya berjalan dengan baik dimana pengelolaan APBDes/keuangan desa masih belum sesuai dengan anggaran yang ada. Jenis penelitian menggunakan penelitian deskriptifKualitatif. Fokus dalam penelitian ini dapat dirumuskan sebagai berikut: Bagaimana proses pengelolahan APBDes, Implementasi Alokasi Dana Desa (ADD) di Desa Tambala Kecamatan tombariri Kabupaten minahasa. Lokasi yang diambil dalam penelitian adalah di Desa Tambala Kecamatan tombariri Kabupaten minahasa. Pengambilan sampel untuk data penelitian kualititaf dilakukan secara purposive dan untuk informasi berikutnya ditentukan dengan Teknik snow ball sampling. Untuk memperoleh data yang berkaitan dengan permasalahan yang akan diteliti, maka dilakukan dengan cara: Wawancara, Studi Dokumentasi/literature. Data yang diperoleh dianalisis menggunakan teknik deskriptif dengan pendekatan kualitatif. Dalam model analisa data terdiri atas tiga komponen yaitu reduksi data, penyajian data, dan penarikan kesimpulan. 


\section{Pendahuluan}

Desa adalah keseluruhan masyarakat hukum yang memiliki batas wilayah yang berwenang untuk mengatur dan mengurus kepentingan masyarakat setempat beserta urusan berdasarkan prakarsa, asal usul dan adat istiadat masyarakat setempat serta hak tradisional yang di akui dan di hormati dalam sistem pemerintahan NKRI. Dana Desa adalah dana yang bersumber dari anggaran pendapatan dan belanja Negara yang diperuntukkan bagi Desa yang di transfer melalui anggaran pendapatan belanja daerah kabupaten/kota dan di gunakan untuk membiayai penyelenggaraan pemerintahan, pembangunan, serta pemberdayaan masyarakat, dan kemasyarakatan. Fokus penting penyaluran dana ini terkait pada implementasi pada pngalokasiaan dana Desa agar bisa sesempurna gagasan inisiatornya. Pendapatan asli Desa adalah pendapatan yang berasal dari kewenangan Desa berdasarkan hak asal usul kewenangan skala lokal Desa.yang dimaksud dengan hasil usaha termasuk juga BUM Desa dan Tanah Bengkok. Alokasi anggaran pendapatan dan belanja Negara bersumber dari belanja pusat dengan mengefektifkan program yang berbasis Desa secara merata dan berkeadilan. Dalam UU.NO.6/2004 Tengtang Desa Pasal 72 dan Ayat 1 di sebutkan sumber pendapatan Desa berasal dari : pendapatan asli Desa, alokasi dari APBN dalam belanja transfer ke daerah/Desa, bagian dari hasil pajak daerah dan distribusi daerah kabupaten kota, paling sedikit $10 \%$ dari pajak dan retribusi daerah, alokasi dana Desa yang merupakan bagian dari dana perimbangan yang di terima di kabupaten/kota ,paling sedikit $10 \%$ dari dana perimbangan yang di terima kabupaten/kota dalam APBD setelah di kurangi alokasi khusus, bantuan keuangan dari APBD Provinsi dan APBD kabupaten kota, hibah dan sumbangan yang tidakmengikat dari pihak ketiga dan lain lain pendapatan Desa yang sah [1]. Anggaran bersumber dari Anggaran Pendapatan dan Belanja Negara (APBN) tersebut adalah anggaran yang di peruntukkan bagi Desa dan Desa adat yang di transfer melalui anggaran pendapatan dan belanjah daerah kabupaten/kota yang digunakan untuk membiayai penyelenggaraan pemerintahan, pembangunan, serta pemberdayaan masyarakat dan kemasyarakatan. Besaran alokasi anggaran yang peruntukannya langsung ke Desa ditentukan $10 \%$ (sepuluh perseratus) dari dan di luar dana transfer daerah (on top) secara bertahap. Sumber pendapatan Desa dari APBN yang di sebut dana Desa di peroleh secara bertahap. Bertahap menurut PP 22/2015 Memiliki dua arti 1. Merujuk pada besaran dana yang akan di terima oleh Desa. Komitmen pemerintah untuk alokasi DD adalah 10 $\%$ dana tersebut melaingkan tergantung pada kemampuan keuangan nasional di satu sisi dan kemampuan Desa dalam memgelola keuangan Desa. Tahap alokasi DD diatur dalam PP 22/2015, yaitu $3 \%$,pada tahun $2015,6 \%$ pada tahun 2016 , dan $10 \%$ pada tahun 2017.merujuk pada tata penyaluran yaitu dilakukan dalamtiga tahap. pencarian DD akan dilakukan pada 1) bulan april $40 \%$ 2) bulan agustus $40 \%$ dan 3) bulan bulan oktober $20 \%$ dari total dana Desa. 2. Bagian hasil pajak daerah dan retribusi daerah kabupaten/kota paling sedikit $10 \%$ (sepuluh perseratus) pajak dan retribusi daerah .alokasi dana Desa paling sedikit $10 \%$ (sepuluh perseratus) dari dana perimbangan yang di terima kabupaten/kota dalamanggaran dan pendapatan belanja daerah setelah dikurangi dana alokasi khusus [2]. Bagi kabupaten yang tidak memberikan alokasi dana Desa, pemerintah pemerintah dapat melakukan penundaan dan/atau pemotongan sebesar alokasi dana perimbangan setelah di kurangi dana alokasi khusus yang seharusnya disalurkan ke Desa. Pentahapan dalam artian tata cara penyaluran untuk ADD dan bagian dari hasil pajak daerah dan retribusi daerah kabupaten/kota di atur dalam peraturan bupati/walikota dengan berpedoman pada peraturan menteri (lihat PP 43/2014 pasal 99 ayat 9(2)) [3]. Besar dan tata penyaluran bantuan keuangan yang bersumber dari anggaran pendapatan dan belanja daerah provinsi atau anggaran pendapatan dan belanja daerah kabupaten/kota ke Desa di lakukan oleh pemerintah provinsi/kabupaten/kota ke Desa sesuai dengan ketersediaan dana dan ketentuan peraturan perundang undangan. Sedangkan kewajiban pemerintah kabupaten/kota yaitu harus melakukan pembinaan ke pada Desa melakukan monitoring dalam penggunaan dana Desa dan bila ada Desa yang melanggar harus di berikan sanksi dan tahun selanjutnya akan di kurangi bantuan dana Desa dan terakhir tugas pemerintah kabupaten/kota harus memberikan laporan kepada pemerintah pusat atas penggunaan dana Desa. Untuk dasar pembinaan itulah pemerintah daerah perlu mengatur lebih lanjut agar Desa lebih memahami dan tidak keluar dari mandat UU Desa tentang sumber sumber pendapatan Desa perlu di buat pedoman peraturan daerah tentang tentang sumber pendapatan Desa.

Berpangkal dari hal tersebut maka pemerintah desa wajib menetapkan keterampilan dalam melaksanakan retribusi serta kemampuan mengatur administrasi dibidang keuangan dengan mengandalkan pendekatan pada masyarakat. Begitu juga dengan pendapatan asli desa bila dikelola dengan baik maka dapat meningkatkan serta menambah keadaan keuangan desa yang bisa digunakan untuk keperluan desa dalam pembiayaan pembangunan. Ketergantungan dana dari pemerintah pusat maupun pemerintah daerah 
sangat kuat, sehingga dalam hal ini pemerintah desa belum dapat memanfaatkan sumbersumber pendapatan desa dengan berbasis pada kekayaan dan potensi desanya.

Dari peran pemerintah desa dalam memanfaatkan hasil potensi desa melalui APBDes sangat diharapkan karena APBDes merupakan instrumen yang sangat penting dalam rangka perwujudan tata pemerintahan yang baik di tingkat desa. Dengan kata lain tata pemerintahan yang baik diukur dari bagaimana pemerintah desa bekerja secara mandiri dalam mengelola potensipotensi yang ada didesa, sehingga pengelolaan APBDes yang disusun benar-benar berorientasi kepada peningkatan pembiayaan pembangunan dan kesejahteraan masyarakat desa serta memenuhi prinsipprinsip seperti transparansi, partisipasi dan akuntabilitas.

Berdasarkan latar belakang masalah di atas, kami sepakat untuk meneliti "Pengaruh pengelolaan APBDes terhadap pembangunan dan penataan di Desa Tambala Kecamatan Tombariri Kabupaten Minahasa Sulawesi utara"

\section{Metode Penelitian}

Jenis penelitian ini merupakan penelitian deskriptif dan menggunakan pendekatan penelitian kualitatif. Moleong, mendefinisikan penelitan kualitatif sebagai penelitian yang bertujuan memahami fenomena yang dialami subjek penelitian, misalnya motivasi, persepsi, tindakan dan lain-lain secara holistic dengan cara mendeskripsikan dalam bentuk katakata secara alamiah dan memanfaatkan metode alamiah. Jadi dalam hal ini tidak boleh mengisolasikan individu atau organisasi kedalam variabel atau hipotesis dan tidak memerlukan angka-angka, tetapi perlu memandangnya sebagai bagian dari suatu keutuhan [4].

Menurut Nawawi (dalam Soejono dan Abdurrahman) jenis penelitian deskriptif merupakan langkah-langkah melakukan representasi objektif tentang gejala pada masalah yang diselidiki. Metode ini menitik beratkan pada observasi dan suasana ilmiah [5]. Ditambahkan oleh Husaini dan Purnomo, bahwa penelitian deskriptif kualitatif adalah menguraikan pendapat responden apa adanya sesuai dengan pertanyaan penelitian, kemudian dianalisis dengan katakata yang melatarbelakangi responden berperilaku seperti itu, direduksi, ditriangulasi, disimpulkan, dan diverifikasi [6].

Dalam penelitian ini, peneliti menggunakan metodologi penelitian deskriptif dengan pendekatan kualitatif karena peneliti ingin menjelaskan penerapan prinsip prinsip akuntabilitas yang dilakukan oleh pemerintah Desa Tambala dalam pengelolaan alokasi dana Desa tahun anggaran 2018 Penelitian ini menggunakan metode penelitian kualitatif, dengan pendekatan studi kasus. Cresswell, menyatakan bahwa penelitian kualitatif merupakan proses penyelidikan untuk memahami masalah sosial atau masalah manusia berdasarkan pada penciptaan gambaran holistik lengkap yang dibentuk dengan kata-kata, melaporkan pandangan informan secara rinci dan disusun dalam sebuah latar alamiah. Melalui pendekatan kritis, penelitian ini menganalisis fenomena sosial yang ada dalam masyarakat, guna menghasilkan pemecahan masalah sosial [7].

\section{Hasil dan Pembahasan}

\section{Kajian Akuntabilitas Pengelolaan APBDES}

Reformasi telah mendorong penerapan good governance di semua level pemerintahan. Syarat-syarat bagi terciptanya good governance adalah adanya transparansi dalam penyelenggaraan pemerintahan,pemerintahan partisipatif bagi masyarakat,dan akuntabilitas [6].

Akuntabilitas meliputi pemberian informasi keuangan kepada masyarakat dan pengguna lainnya sehingga memungkinkan bagi mereka untuk menilai pertanggung jawaban pemerintah atas semua aktifitas yang dilakukan, bukan hanya laporan keuangan saja namun harus memberikan informasi dalam pembuatan keputusan ekonomi, sosial dan politik. Selain itu akuntabilitas adalah upaya Negara dalam hal ini yaitu pemerintah dalam menciptakan penyelenggaraan pemeritahan kearah yang lebih baik dengan berlandaskan good governance.

Akuntabilitas diharapkan dapat memperbaiki kualitas serta kinerja dari instansi pemerintah agar menjadi pemerintahan yang transparan dan berorientasi pada kepentingan publik. Adapun konsep dari akuntabilitas didasarkan pada individu-individu atau kelompok jabatan dalam tiap klasifikasi jabatan bertanggungjawab pada kegiatan yang Iingin dilakukannya [6]. Guna mewujudkan akuntabilitas khususnya dalam instansi pemerintah Lembaga Adminsitrasi Negara (LAN) bekerjasama dengan Badan

$$
\text { Pengawasan Keuangan dan }
$$

Pembangunan (BPKP) telah memberikan pedoman atau prinsip prinsip dalam penerapan akuntabilitas disuatu instansi. Selain untuk menjadikan akuntabilitas tersebut efektif, adanya prinsip-prinsip akuntabilitas harus didukung komitmen yang kuat dari organisasi yang mempunyai wewenang dan bertanggung jawabldi bidang pengawasan dan penilaian [8]. 


\section{Manajemen Keuangan Daerah}

Memahami sebuah pengelolaan keuangan daerah semuanya berpijak dari pemahaman tentang anggaran daerah. Salah satu pilar keberhasilan keuangan otonomi daerah adalah bagaimana pemerintah baik pusat maupun daerah mampu menggunakan dan memanfaatkan sumber daya yang dimiliki secara lebih efektif dan efisien melalui sumber-sumber daya publik dalam membiayai aktifitas pembangunan yang dilakukan [6]. Artinya bahwa dengan pengelolaan sumber keuangan daerah yang efektif dan efisien maka program-program dalam pelaksanaan otonomi daerah akan semakin mencapai suatu keberhasilan. Sehingga pengelolaan keuangan daerah tersebut dikenal dengan manajemen keuangan daerah. Anggaran daerah merupakan bagian dari manajemen keuangan daerah yang secara garis besar dibagi menjadi dua bagian yaitu manajemen penerimaan daerah dan manajemen pengeluaran daerah. Sesuai dengan Mardiasmo bahwa Anggaran daerah atau APBD (Anggaran Penerimaaan dan Pendapatana Daerah) adalah rencana kerja pemerintah daerah dalam bentuk uang (rupiah) dalam satu periode tertentu (satu tahun). Semua bentuk organisasi, sektor swasta maupun sektor public pasti akan melakukan penganggaran yang pada dasarnya merupakan cara untuk mencapai visi dan misinya. Untuk itu manajemen keuangan dilaksanakan berdasarkan pada prinsip-prinsip yang harus dipatuhi sebagai cara untuk mengontrol kebijakan keuangan daerah. Seperti yang dijelaskan oleh Mardiasmo Prinsip manajemen keuangan daerah meliputi akuntabilitas, Value For Money, Transparansi, Pengendalian, dan Kejujuran [4].

\section{Anggaran Penerimaan dan Belanja Desa} (APBDes)

APBDes merupakan suatu rencana keuangan tahunan Desa yang ditetapkan berdasarkan peraturan Desa yang mengandung prakiraan sumber pendapatan dan belanja untuk mendukung kebutuhan program pembangunan Desa yang bersangkutan [9]. Dengan adanya APBDes penyelenggaraan pemerintahan Desa akan memiliki sebuah rencana strategis yang terukur berdasarkan anggaran yang tersedia dan yang dipergunakan. Anggaran Desa tersebut dipergunakan secara seimbang berdasarkan prinsip. pengelolaan keuangan daerah agar tercipta cita-cita good governance. Oleh karena itu APBDes mendorong pemerintah Desa agar mampu memberikan pelayan terbaik kepada masyarakat melalui perencanaan pembangunan yang tertuang di dalamnya. Salah satu sumber pendapatan Desa berupa dana perimbangan keuangan pusat dan daerah yang sudah dianggarkan $10 \%$ dari APBD. Hal tersebut juga dijelaskan Sumpeno bahwa dalam rangka meningkatkan pemberdayaan, kesejahteraan dan pemerataan pembangunan di peDesaan melalui dana APBD kabupaten, propinsi dan pemerintah (nasional), maka perlu direalisasikan dalam APBD masing-masing sebesar $10 \%$ untuk dana alokasi Desa [9].

\section{Alokasi Dana Desa (ADD)}

Pengertian Alokasi Dana Desa (ADD) Menurut Peraturan Pemerintah Republik Indonesia Nomor 72 Tahun 2005 Tentang Desa, alokasi dana Desa merupakan bagian dari dana perimbangan keuangan pusat dan daerah yang diterima oleh kabupaten/kota untuk Desa paling sedikit 10\% (sepuluh peratus), yang pembagiannya untuk Desa secara proporsional [10]. Berdasarkan Peraturan Menteri Dalam Negeri Nomor 37 Tahun 2007 Tentang Pedoman Pengelolaan Keuangan Desa disebutkan bahwa alokasi dana Desa berasal dari APBD kabupaten/kota yang bersumber dari bagian dana perimbangan keuangan pusat dan daerah yang diterima oleh kabupaten/kota untuk Desa paling sedikit $10 \%$ (sepuluh persen) [11]. Alokasi Dana Desa

(ADD) Menurut Undang-Undang Nomor 6 Tahun 2014 Tentang Desa merupakan bagian dari dana perimbangan yang diterima kabupaten/kota paling sedikit $10 \%$

(sepuluh perseratus) dalam anggaran pendapatan dan belanja daerah setelah dikurangi dana alokasi khusus3. Dan menurut Peraturan Daerah Kabupaten Kepulauan Meranti Nomor 16 Tahun 2011 Tentang Keuangan Desa bahwa anggaran pendapatan dan belanja Desa selanjutnya disingkat APBDesa adalah rencana keuangan tahunan Desa yang dibahas dan disetujui bersama oleh pemerintah Desa dan Badan Permusyawaratan Desa (BPD) yang ditetapkan dengan Peraturan Desa. Dari pengertian diatas dapat penulis simpulkan bahwa Alokasi Dana Desa (ADD) merupakan bagian keuangan Desa yang diperoleh dari bagi hasil pajak daerah dan bagian dari dana perimbangan keuangan pusat dan daerah yang diterima oleh kabupaten/kota untuk Desa yang dibagikan secara proporsional.

\section{Dasar Hukum Tentang Alokasi Dana Desa (ADD)}

Sesuai dengan amanat UndangUndang Dasar Negara Republik Indonesia Tahun 1945 (UUD 1945), pemerintah daerah berwenang mengatur dan mengurus sendiri urusan pemerintahan menurut asas otonomi dan tugas pembantuan. Pemberian otonomi kepada daerah diarahkan untuk mempercepat terwujudnya kesejahteraan masyarakat melalui peningkatan pelayanan publik, pemberdayaan, dan peran serta masyarakat dalam pembangunan disegala bidang kehidupan [12]. Selanjutnya, agar fungsi 
pemerintahan daerah terlaksana secara optimal, perlu diikuti dengan pemberian sumber-sumber penerimaan yang cukup kepada daerah, disamping kemampuan daerah sendiri dalam menggali sumber pendapatan daerah yang dapat dijadikan kekuatan dalam mempercepat pertumbuah ekonomi. Bagi Republik Indonesia sebagai negara kesatuan, istilah "Pemerintahan yang di desentralisasikan" merupakan alternatif istilah yang mungkin sesuai untuk desentralisasi kewenangan pusat kepada daerah.

Hal ini berdasarkan pasal 10 ayat (3) Undang-Undang Nomor 32 Tahun 2004 yang berbunyi: Urusan pemerintahan yang menjadi urusan Pemerintah sebagaimana dimaksud pada ayat (1) meliputi: a.Politik luar negeri; $b$. Pertahanan; c. Keamanan; d. Yustisi; e. Moneter dan fiskal nasional; dan f. Agama." Pada pasal 10 ayat (3) tersebut menyatakan bahwa tidak semua urusan pemerintah pusat menjadi urusan pemerintah daerah. Demikian

pula masih dikenal adanya tugas dekonsentrasi maupun tugas pembantuan sebagai mana diatur dalam pasal 10 ayat (5) UndangUndang Nomor 32 Tahun 2004 yaitu: Dalam urusan pemerintahan yang menjadi kewenangan menggali sumber pendapatan daerah yang dapat dijadikan kekuatan dalam mempercepat pertumbuah ekonomis. Bagi Republik Indonesia sebagai Negara kesatuan, istilah "Pemerintahan yang di desentralisasikan" merupakan alternatif istilah yang mungkin sesuai untuk desentralisasi kewenangan pusat kepada daerah.

Kepala Desa mempunyai peran yang sangat penting juga karena sesuai dengan Permendagri No 37 tahun 2007 kepala Desa Tambala mempunyai hak dan kewajiban untuk mengelola keuangan yang ada didesa tersebut [13]. Oleh sebab itu kendala yang dihadapi Desa Tambala yaitu tentang APBDes dimana APBDes tidak sesuai dengan peraturan desa yang ada karena banyak anggaran yang belum jelas dan juga masih ada datadata yang belum lengkap. Oleh sebab itu keuangan desa harus dikelola berdasarkan azas-azas sebagai berikut :

\section{Transparansi}

Dalam pasal 4 ayat 7 Peraturan Menteri dalam Negeri Republik Indonesia Nomor 13 Tahun 2006, tentang pedoman pengelolaan keuangan daerah, dikatakan transparansi adalah prinsip keterbukaan yang memungkinkan masyarakat untuk mengetahui dan mendapatkan akses informasi seluasluasnya tentang keunagan daerah [14]. Dengan adanya transparansi menjamin akses atau kebebasan bagi setiap orang untuk memperoleh informasi tentang kebijakan, proses pembuatan dan pelaksanaannya, serta hasilhasil yang dicapai
Transparansi menjadi sangat penting bagi pelaksanaan fungsi-fungsi pemerintah dalam menjalankan mandat dari rakyat. Mengigat pemerintah memiliki kewenagan mengambil berbagai keputusan penting yang berdampak bagi orang banyak, pemerintah harus menyediakan informasi yang lengkap mengenai apa yang dikerjakannya.

Dengan transparansi, kebohongan sulit untuk disembunyikan.

\section{Akuntabilitas}

Akuntabilitas (accountability) adalah kewajiban untuk memberikan pertanggungjawaban atau menjawab dan menerangkan kinerja dan tindakan seseorang badan hukum pimpinan suatu organisasi kepada pihak yang memiliki hak atau berkewenangan untuk meminta keterangan atau pertanggungjawaban. Dalam pelaksanaan akuntabilitas dilingkungan instansi pemerintah, perlu diperhatikan prinsip-prinsip sebagai berikut : 1) Harus ada komitmen dari pimpinan dan seluruh staf instansi untuk melakukan pengelolaan pelaksanaan misi agar akunntabel; 2) Harus merupakan suatu system yang dapat menjamin penggunaan sumber-sumber daya secara konsisten dengan peraturan perundang-undangan yang berlaku; 3) Harus dapat menunjuk tingkat pencapaian tujuan dan sasaran yang telah ditetapkan; 4) Harus berorientasi pada pencapaian visi dan misi serta hasil dan manfaat yang diperoleh; 5) Harus jujur, objektif, transparan dan inovatif sebagai katalisator perubahan manejemen instansi pemerintah dalam bentuk pemutakhiran metode dan teknik pengukuran kinerja dan penyusunan laporan akuntabilitas [15].

\section{Partisipatif}

Dalam permendagri No 37 Tahun 2007 Tentang Penggelolaan Keuangan Desa, partisipasi memakai kata partisipatif, yaitu keikutsertaan danketerlibatan masyarakat secara aktif dalam proses pembangunan. Partisipasi masyarakat dalam penentuan kebijakan public menjadi kekuatan pendorong untuk mempercepat terpenuhinya prinsip akuntabilitas dari penyelenggaraan pemerintahan desa. Dalam penganggaran partisipasi masyarakat sangat penting untuk mencegah kebijakan-kebijakan yang menyimpang.

Dari ketiga azas di atas inilah penggeloaan keungan desa/APBDesa bisa dapat terarah secara teratur sesuai dengan harapan yang diinginkan oleh Desa Tambala agar dapat membiayai pembangunan desa.

\section{Kesimpulan}

Berdasarkan hasil uraian pada bab-bab sebelumnya, dapatlah ditarik kesimpulan bahwa 
peran pemerintah desa (kepala desa bersama perangkat desa) dalam pengeloaan APBDes di desa Tambala belum sepenuhnya berjalan dengan baik dimana pengelolaan APBDes/keuangan desa masih belum sesuai dengan anggaran yang ada. Maka dari itu pemerintah desa harus lebih bekerja keras lagi dalam mengelola APBDes yang ada karena dengan begitu semua anggaran yang sudah disepakati bersama dalam peraturan desa yang ada akan terlaksana sesuai dengan tujuan pembangunan desa yang sudah ditentukan, juga dapat mengelola keungan dan sumber perndapatan desa sesuai dengan azas-azas yang sudah dikemukakan tadi yaitu transparansi, akuntabilitas dan partisipatif dengan begitu semua pembanguna desa berjalan secara efektif dan efisien. Dari kendala inilah yang menjadi catatan penting kepada pemerintah desa Tambala dengan kendala ini administrasi seringkali terabaikan oleh sebab itu adanya kerjasama antar pemerintah desa, masyarakat, pemerintah kecamatan dan kabupaten yang ada agar penggelolaan APBDes bisa terarah dan sesuai dengan peraturan yang berlaku.

\section{Referensi}

[1] Undang - Undang No.6 Tahun 2004 Tentang Desa

[2] PP 22 Tahun 2015 tentang Perubahan Atas PP 60 Tahun 2014 tentang Dana Desa Yang Bersumber dari APBN

[3] Peraturan Pemerintah No 43 /2014 tentang Peraturan Pelaksanaan UU No.6/2014

[4] Mardiasmo. 2004. Otonomi dan Manajemen Keuangan Daerah. Yogjakarta: Andi Offset. Moleong,

[5] Lexy. 2010. Metodologi Penelitian Kualitatif. Bandung: PT. Remaja Rosda Karya.
[6] Sedarmayanti. 2009. Reformasi Administrasi Publik, Reformasi Birokrasi, dan Kepemimpinan Masa Depan (Mewujudkan PelayananPrima dan Kepemerintahan yang Baik). Bandung: Rafiko Aditama. Soejono, dan Abdurrahman. 1999.

[7] Usman, Husaini dan Purnomo, Setiady. 2009. Metodologi Penelitian Sosial. Jakarta: Bumi Aksara. Waluyo. 2007. Manajemen Publik (Konsep, Aplikasi, dan Implementasinya dalam Pelaksanaan Otonomi Daerah). Bandung: CV. Mandar Maju.

[8] Creswell, John .W. (2009). Research Design: Pendekatan Kualitatif, Kuantitatif, dan Mixed. Yogyakarta: Pustaka Pelajar. Akuntabilitas dan Good Governance, Modul 1-5, Modul Sosialisasi Sistem Akuntabilitas Kinerja Instansi Pemerintah (AKIP), LAN BPKP RI. Jakarta.

[9] Metode Penelitian Kuantitatif, Kualitatif, dan $R \& D$. Bandung: Alfabeta. Sumpeno, Wahjudin. 2011. Perencanaan Desa Terpadu. Banda Aceh: Read Peraturan Pemerintah Republik Indonesia Nomor 72 Tahun 2005 Tentang Desa

[10] Peraturan Menteri Dalam Negeri Nomor 37 Tahun 2007 Tentang Pedoman Pengelolaan Keuangan Desa

[11] Undang-Undang Dasar Negara Republik Indonesia Tahun 1945 (UUD 1945)

[12] Permendagri No 37 tahun 2007

[13] Peraturan Menteri dalam Negeri Republik Indonesia Nomor 13 Tahun 2006

[14] LAN \& BPKP. 2000. Akuntabilitas dan Good Governance. Jakarta: Lembaga. Administrasi Negara. 